\title{
PENGARUH DAYA GELOMBANG MIKRO TERHADAP RENDEMEN, MUTU DAN KOMPONEN BIODIESEL DARI BIJI KEMIRI YANG DIPROSES SECARA TRANSESTERIFIKASI IN SITU
}

\author{
Effect of Microwave Power on Yield, Quality and Component of Biodiesel from \\ Candle Nut Seed Processed Through In Situ Transesterification
}

\author{
Mahlinda*, Lancy Maurina, dan Ellysa \\ Balai Riset dan Standardisasi Industri Banda Aceh \\ Jl. Cut Nyak Dhien No. 377 Lamteumen Timur Banda Aceh \\ "e-mail: mahlinibr_aceh@yahoo.com
}

\begin{abstract}
Abstrak: Transesterifikasi in situ biodiesel adalah metode untuk produksi biodiesel menggunakan pelarut alkohol dengan bantuan katalis asam atau basa melalui pemanasan konvensional sederhana. Namun, metode konvensional ini dianggap tidak efisien karena memerlukan energi dalam jumlah besar untuk memanaskan media dan proses reaksinya berlangsung lama. Dewasa ini telah dikembangkan metode produksi biodiesel yang lebih efisien dan cepat, yaitu menggunakan gelombang microwave. Tujuan dari penelitian ini untuk mempelajari pengaruh daya gelombang mikro terhadap rendemen, mutu dan komponen biodiesel dari biji kemiri yang diproses melalui transesterifikasi in situ. Proses transesterifikasi in situ berjalan pada daya gelombang mikro 450, 600 dan 800 watt, waktu reaksi empat menit, rasio metanol 25:1 (g/g), rasio co-solvent 0,5:1 (g/g) dan $5 \%$ konsentrasi $\mathrm{KOH}$ katalis. Hasil penelitian menunjukkan bahwa rendemen tertinggi $85,58 \%$ diperoleh pada daya gelombang mikro 600 watt dengan waktu reaksi empat menit. Hasil uji mutu biodiesel berdasarkan SNI 7182-2012 menunjukkan nilai viskositas kinematik dan angka asam memenuhi standar, namun terhadap masa jenis belum memenuhi standar. Hasil analisa biodiesel menggunakan GC-MS pada ketiga daya gelombang mikro mengandung metil stearat, metil palmitat dan metil miristat. Daya gelombang mikro berpengaruh terhadap rendemen biodiesel tetapi tidak berpengaruh signifikan terhadap mutu dan komponen biodiesel.
\end{abstract}

Kata kunci : biodiesel, gelombang mikro, transesterification in situ, kemiri.

\begin{abstract}
The in situ transesterification of biodiesel by conventional heating is simple but need high energy and long reaction time to produce biodiesel. Microwave radiation, delivers energy directly to the reactants, therefore, heat transfer is more effective. The research aims was to explore the effect of microwave power toward yield, quality and compound of biodiesel from candlenut seed through in situ transesterification. The in situ transesterification was run on microwave power 450, 600 and 800 watts, 4 minutes, methanol ratio $25: 1(\mathrm{w} / \mathrm{w})$, co-solvent ratio $0.5: 1(\mathrm{w} / \mathrm{w})$ and $5 \% \mathrm{KOH}$ catalyst concentration. The results showed, highest biodiesel yield $85.58 \%$ was obtained under the microwave power of 600 watts with reaction time 4 minutes. A test result of biodiesel quality according to SNI 7182-2012 showed kinematic viscosity and acid value was approriate with standars, meanwhile density test was below of SNI standars. GC-MS analysis of biodiesel produced under 450, 600 and 800 watts microwave power showed, the main components were methyl stearate, methyl palmitate and methyl miristate but the percentage component was slightly different according to the various microwave power. It can be concluded that microwave power just affected on biodiesel yield but not significant affected on biodiesel quality and component.
\end{abstract}

Kata kunci : biodiesel, gelombang mikro, transesterification in situ, kemiri.

\section{PENDAHULUAN}

Minyak solar merupakan salah satu sumber energi penting yang berasal dari hasil pertambangan di dalam perut bumi digunakan untuk industri dan transportasi. Dalam penggunaannya sehari-hari, sumber energi ini menghadapi beberapa kendala antara lain: (1) minyak solar masuk dalam sumber energi yang tidak dapat diperbaharui (non renewabe energy), ketika sumberenergi tersebut habis karena proses penambangan yang dilakukan secara besar-besaran dan terus menerus tidak dapat diproduksi ulang, (2) minyak solar berbasis fosil ini dituding sebagai salah satu penghasil polusi karena hasil pembakaran bahan bakar solar yang mengandung Sox, Nox, hidrokarbon dan komponen karsinogenik lainnya dalam 
jangka panjang akan berdampak pada peningkatan efek rumah kaca dan terjadinya pemanasan global (global warming) dan diperkirakan suhu bumi akan naik 4-6 ${ }^{\circ} \mathrm{C}$ lebih panas diakhir abad ini (Oxfam, 2014). Menghadapi masalah tersebut, para Peneliti diseluruh dunia berinovasi untuk mencari sumber energi baru yang dapat diperbaharui dan ramah lingkungan, salah satunya adalah dengan menggunakan biodiesel.

Biodiesel adalah sejenis bahan bakar pengganti solar yang diproduksi dari berbagai jenis bahan baku nabati (Ramos et a.l, 2009) atau lemak hewani (Saraf \& Thomas., 2007) melalui proses transesterifikasi menggunakan pelarut dari jenis alkohol dengan bantuan katalis baik katalis. Biodiesel yang diproduksi ini mempunyai karakteristik yang sama dengan bahan bakar fosil (solar) sehingga dapat digunakan secara langsung atau dicampur solar sebagai bahan bakar mesin diesel tanpa perlu memodifikasi mesin (Dwivedi et al., 2013; Xue et al., 2011). Dibandingkan dengan penggunaan bahan bakar solar berbasis fosil, penggunaan biodiesel memiliki beberapa keuntungan diantaranya proses pelumasan mesin lebih baik, dapat diperbaharui, diproduksi secara lokal, ramah lingkungan dan tidak beracun (Jain \& Sharma, 2010; Haas et al., 2007).

Salah satu cara untuk memproduksi biodiesel yang banyak diaplikasikan saat ini adalah dengan mereaksikan campuran bahan baku minyak dengan alkohol dan katalis dalam jumlah tertentu menggunakan pemanasan konvensional. Proses pemanasan konvensional bekerja dengan cara mentransferkan energi panas ke reaktan melalui proses konveksi, konduksi dan radiasi di permukaan reactor. Namun, proses perpindahan panas (heat transfer) dengan cara konvensional dianggap tidak efisien lagi karena memerlukan energi dalam jumlah besar untuk memanaskan media dan juga proses reaksinya berlangsung lama (umumnya antara 30 menit hingga 8 jam) untuk memperoleh rendemen tertinggi (Zare et al., 2013). Dewasa ini, beberapa penelitian telah dilakukan untuk memproduksi biodiesel yang lebih efisien dan cepat, dengan menggunakan gelombang mikro (microwave). Dibandingkan dengan proses konvensional, penggunaan gelombang mikro memiliki beberapa keuntungan seperti waktu reaksi lebih cepat, konsumsi energi yang lebih rendah, meningkatkan rendemen dan mengurangi penggunaan pelarut alkohol (Marwan et al., 2015; Surati et al., 2012). Penelitian ini bertujuan untuk mempelajari pengaruh besaran daya gelombang mikro (microwave) terhadap rendemen, mutu dan komposisi biodiesel dari biji kemiri menggunakan proses transesterifikasi in situ.

\section{METODOLOGI}

\section{Bahan dan Alat}

Bahan baku untuk memproduksi biodiesel berupa biji kemiri kupas yang diperoleh dari toko-toko bumbu di seputaran Banda Aceh, metanol teknis, chloroform PA (Merck), dan KOH PA (Merck). Sedangkan peralatan yang digunakan berupa oven mikrowave (Samsung ME731K), pengaduk mekanik (SciLOGEX OS20S), timbangan digital (RADWAG WPS 2100/C/1), blender, oven pengering (Memmert), rotary evaporator (Laborota 4003), labu reaksi 1000 $\mathrm{mL}$ (Pyrex), labu pemisah $250 \mathrm{~mL}$ (Schott), piknometer $5 \mathrm{ml}$ (Schott) dan viscometer oswald (lokal). dan Gas ChomatographyMassa (QP2010). Rangkaian peralatan mikrowave yang digunakan pada penelitian ini disajikan pada Gambar 1.

\section{METODE}

\section{Prosedur Penelitian}

Persiapan bahan baku dimulai dengan mengumpulkan biji kemiri yang diperoleh dari pedagang hasil bumi di pasar Aceh Banda Aceh. Kemiri yang diperoleh selanjutnya dilakukan sortasi untuk memisahkan kotoran, bebatuan dan biji busuk. Biji kemiri yang telah disortir tersebut dikeringkan di dalam oven pengering selama 12 jam pada suhu $60^{\circ} \mathrm{C}$. Biji kemiri kering dengan kadar air $<1 \%$ diambil 
dan ditimbang sebanyak 100 gr/proses lalu dikecilkan ukurannya menggunakan blender hingga mencapai ukuran antara 3040 mesh. Metanol, co-solvent (Kloroform) dan katalis $\mathrm{KOH}$ ditimbang seusai dengan variabel penelitian dan dicampur dengan bubuk kemiri didalam labu reaksi selanjutnya dimasukkan kedalam oven microwave. Daya mikrowave diatur pada variasi 450, 600 dan 800 watt, sedangkan waktu reaksi diatur pada kondisi tetap (4 menit). Bubuk kemiri yang telah diproses tersebut dipisahkan menggunakan saringan sedangkan cairan reaktan berupa biodiesel, metanol dan kloroform dipisahkan menggunakan rotary evaporator selama 2 jam pada temperatur reaksi $75{ }^{\circ} \mathrm{C}$. Selanjutnya hasil ekstrak dari rotary evaporator diambil, dimasukkan kedalam labu pemisah dan diendapkan selama 1-2 jam untuk memisahkan gliserol dari crude biodiesel. Lapisan gliserol yang terdapat dibagian bawah labu pemisah dibuang, sedangkan produk crude biodiesel dicuci menggunakan air hangat (40-50 $\left.{ }^{\circ} \mathrm{C}\right)$ sebanyak $2-3$ kali hingga air cucian berwarna bening. Biodiesel yang diperoleh kemudian dipanaskan pada temperatur $110{ }^{\circ} \mathrm{C}$ menggunakan hot plate untuk menghilangkan sisa air dan pelarut yang ada di dalam biodiesel tersebut.

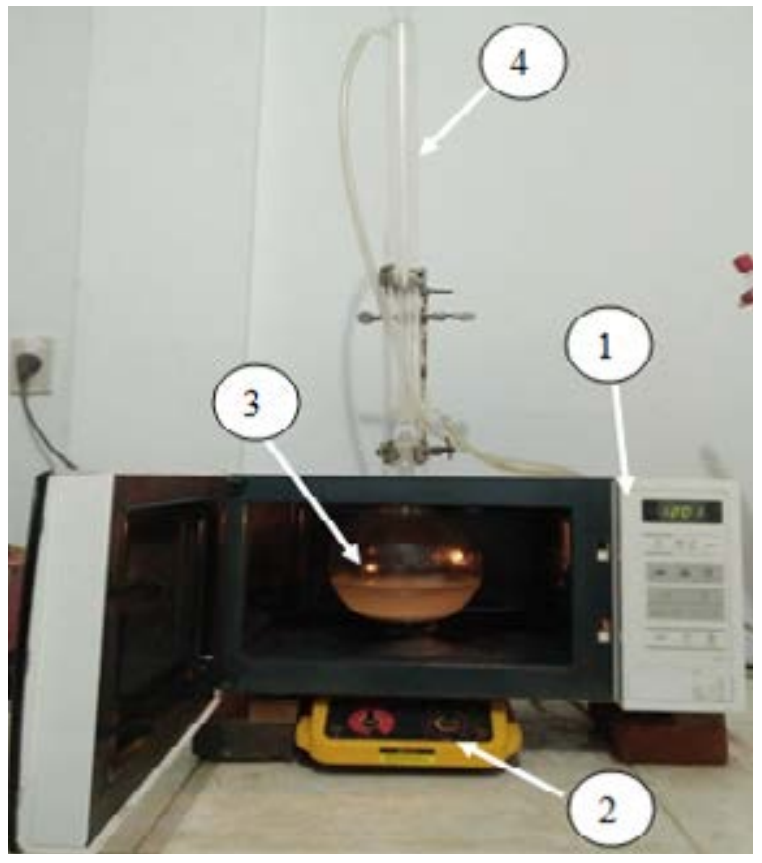

Gambar 1. Rangkaian Peralatan Mikrowave
Keterangan:
1. Oven microwave
3. Reaktan
2. Pengaduk
4. Kondensor

\section{Variabel Penelitian}

Variabel peneltian yang digunakan dalam penelitian ini terdiri dari dua variabel yaitu variabel tetap dan variabel bebas.

a) Variabel tetap

- Rasio metanol terhadap berat bahan baku $(25: 1) \mathrm{g} / \mathrm{g}$.

- Rasio co-solvent terhadap berat bahan baku $(0,5: 1) \mathrm{g} / \mathrm{g}$.

- Jumlah katalis (3\%)

- Waktu reaksi: 4 menit

b) Variabel bebas

- Daya gelombang mikro: 450, 600 dan 800 watt

\section{Perhitungan Rendemen Biodiesel}

Rendemen biodiesel yang diperoleh dihitung menggunakan rumus sebagai berikut:

Rendemen

Berat Biodisel (gR)

Berat bubuk kemiri (gr)x kandungan minyak (0\%)

$(\%)=\times 100 \%$

\section{Pengujian Produk Biodiesel}

Produk biodiesel yang diperoleh dari proses transesterifikasi in situ menggunakan gelombang mikro, sampelnya di ambil dan dilakukan pengujian sesuai dengan $\mathrm{SNI}$ 7182:2012 meliputi uji massa jenis $\left(\mathrm{kg} / \mathrm{m}^{3}\right)$, viskositas kinematik $\left(\mathrm{mm}^{2} / \mathrm{s}\right)$ dan angka asam (mg-KOH/gr). Hasil yang diperoleh dibandingkan dengan standar SNI.

\section{Analisa Komponen Biodiesel}

Analisa komponen biodiesel dilakukan menggunakan peralatan Gas Chomatography-Mass Spectrometry (GC-MS) dan menghitung persentasenya berdasarkan puncak (peak). 


\section{HASIL DAN PEMBAHASAN}

\section{Rendemen biodiesel}

Salah satu faktor penentu kelayakan proses produksi biodiesel adalah dari rendemen yang diperoleh dimana semakin besar rendemen yang diperoleh semakin menguntungkan dan menentukan tingkat keberhasilan proses produksi biodiesel. Penggunaan gelombang mikro untuk memproduksi biodiesel bukan hanya mengurangi waktu proses dan mempercepat proses pemisahannya tetapi juga dapat meningkatkan rendemen biodiesel (Refaat et al, 2008). Pengaruh daya gelombang mikro terhadap perolehan biodiesel dengan waktu reaksi empat menit disajikan pada Gambar 2. Data Gambar 2 menunjukkan bahwa bertambahnya daya gelombang mikrowave yang dipancarkan akan menaikan rendemen biodiesel sampai pada batas tertentu dan setelah mencapai batas tersebut, rendemen biodiesel akan mengalami penurunan. Dari Gambar 2 terlihat ketika gelombang mikro diatur sebesar 450 watt, rendemen biodiesel yang diperoleh sebanyak $66,91 \%$.
Ketika gelombang mikro diatur sebesar 600 watt, rendemen biodiesel yang diperoleh meningkat sebanyak $85,58 \%$ dan merupakan rendemen tertinggi yang diperoleh. Akan tetapi ketika gelombang mikro diatur diatas 600 wat, rendemen biodiesel mengalami penurunan, bahkan ketika gelombang mikro diatur sampai 800 wat, rendemen biodiesel yang diperoleh sebanyak $81,67 \%$ mengalami penurunan sebesar $3,91 \%$. Ketika daya gelombang mikro yang dipancarkan masih rendah, dayanya belum cukup kuat untuk mendorong reaksi transesterifikasi in situ ke arah produk, selain itu temperatur yang dihasilkan juga masih rendah menyebabkan perolehan rendemen biodiesel juga rendah. Sebaliknya, ketika daya gelombang mikro yang dipancarkan terlalu tinggi, disamping dapat menyebabkan kerusakan molekul organik trigliserida juga dapat menyebabkan kenaikan suhu melebihi titik didih metanol sehingga metanol berubah menjadi fase uap dan mempengaruhi proses pembentukan biodiesel sehingga rendemen yang diperoleh akan menurun (Saifuddin et al., 2004., Haryanto et al., 2015).

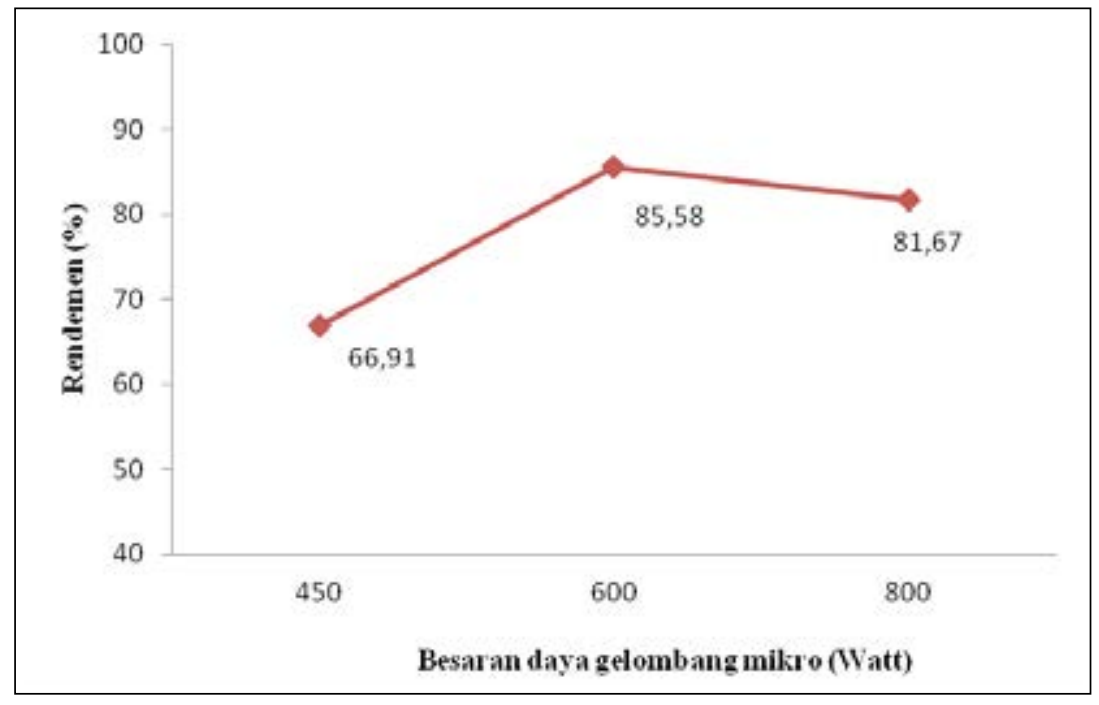

Gambar 2. Pengaruh Besaran Daya Gelombang Mikro Terhadap Rendemen Biodiesel

\section{Mutu Biodiesel}

\section{Massa Jenis}

Massa jenis atau juga dikenal dengan istilah densitas yaitu jumlah minyak per satuan volume yang diukur pada temperatur $40{ }^{\circ} \mathrm{C}$. Umumnya karakteristik biodiesel seperti angka setana (cetane number) dan nilai bakar (heating value) berhubungan 
langsung dengan nilai masa jenis dari produk biodiesel tersebut. Oleh sebab itu, nilai masa jenis biodiesel berpengaruh langsung terhadap kinerja kinerja mesin diesel (Alptekin \& Canaki, 2008). Selain itu, massa jenis juga dapat menunjukan karakteristik biodiesel seperti sifat biodiesel pada suhu rendah, kualitas penyalaan biodiesel di ruang bakar dan terjadinya pembentukan asap pada saat biodiesel dibakar (Sundaryono, 2011).

Adapun perbedaan masa jenis produk biodiesel berdasarkan besaran daya gelombang mikro yang dipancarkan disajikan pada Gambar 3. Berdasarkan Gambar 3 diketahui bahwa besaran daya gelombang mikro 450 watt nilai massa jenis sebesar 836 $\mathrm{kg} / \mathrm{m}^{3}$ dan pada daya gelombang mikro 600 dan 800 watt nilai massa jenis sama besar yaitu $842 \mathrm{~kg} / \mathrm{m}^{3}$. Namun ketiga nilai massa jenis ini pada dasarnya tidak memenuhi standar SNI yang ditetapkan. Mittelbatch \& Remschmidt (2004) menyatakan bahwa faktor yang mempengaruhi perbedaan massa jenis biodiesel adalah tingkat kemurnian bahan baku dan komposisi asam lemaknya dimana massa jenis akan meningkat seiring dengan peningkatan jumlah ikatan rangkap pada asam lemak dan penurunan panjang rantai karbon. Dalam hal ini, peningkatan daya gelombang mikro belum mampu untuk merubah komposisi ikatan rangkap asam lemak sehingga nilai massa jenisnya tidak berubah secara signifikan.

\section{Viskositas Kinematik}

Viskositas kinematik di definisikan sebagai ukuran ketahanan suatu cairan untuk mengalir pada kondisi tertentu. Seperti diketahui, sistim pembakaran pada mesin diesel memerlukan bahan bakar dengan bentuk partikulat halus agar dapat terbakar dengan sempurna. Ketika nilai viskositas kinematik terlalu tinggi, bahan bakar kesulitan untuk mengalir secara tepat keruang bakar dan bentuk partikulatnya tidak halus sehingga berpengaruh terhadap proses pembakaran bahan bakar yang secara langsung berpengaruh terhadap kinerja mesin diesel. Perbedaan nilai viskositas kinematik biodiesel yang dihasilkan berdasarkan besaran daya gelombang mikro yang dipancarkan disajikan pada Gambar 4.

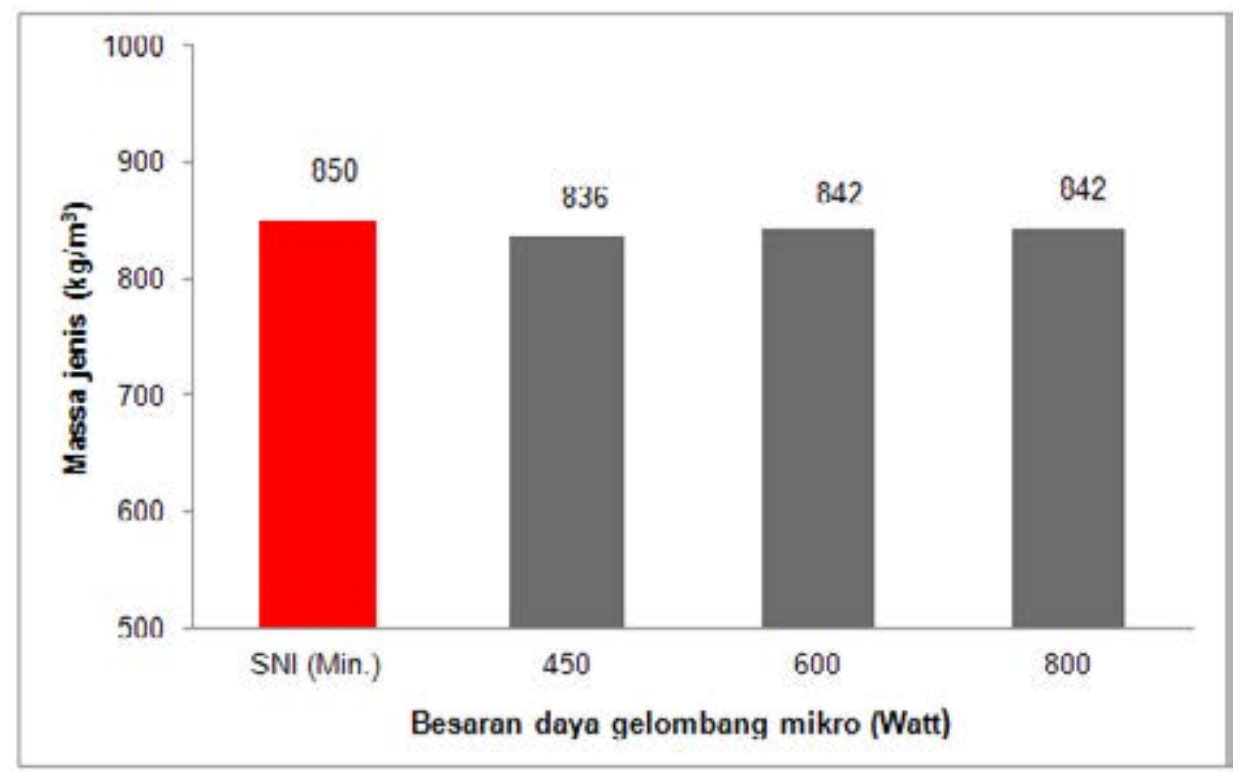

Gambar 3. Pengaruh Besaran Daya Gelombang Mikro Terhadap Massa Jenis Biodiesel 


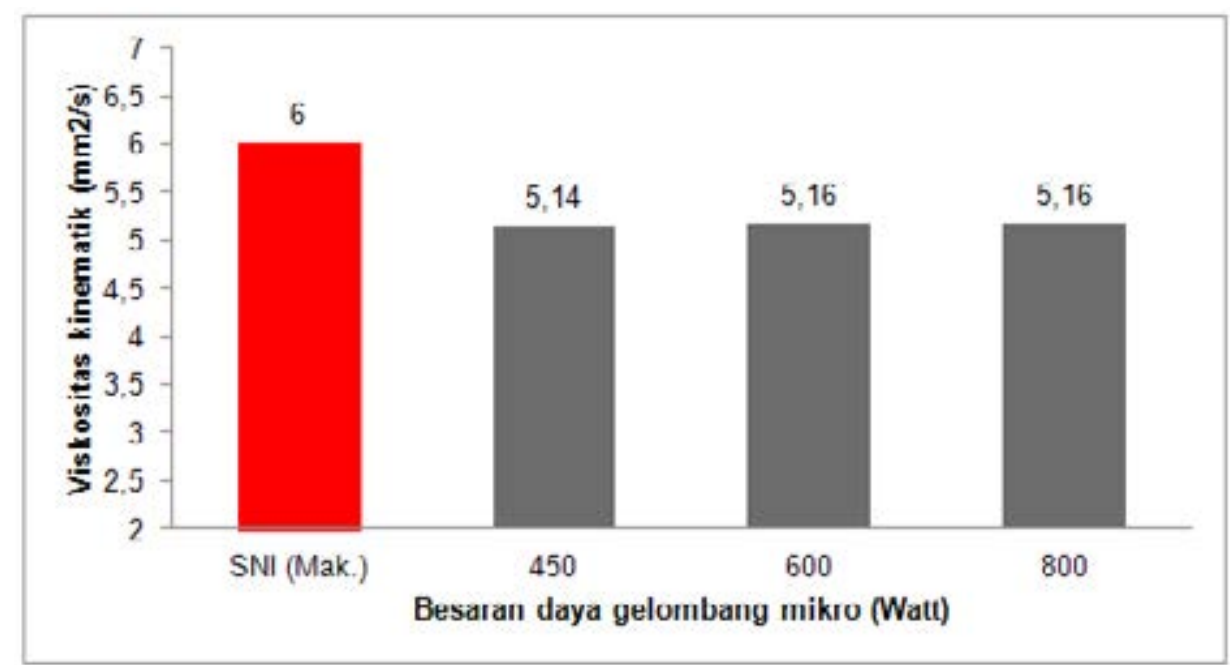

Gambar 4. Pengaruh Besaran Daya Gelombang Mikro Terhadap Viskositas Kinematik Biodiesel

Data dari Gambar 4 menunjukkan bahwa besaran daya gelombang mikro yang dipancarkan tidak berpengaruh signifikan terhadap nilai viskositas kinematik dari produk biodiesel yang dihasilkan. Ketika daya gelombang mikro yang digunakan sebesar 450 watt menghasilkan nilai viskositas kinematik sebesar $5,14 \mathrm{~mm}^{2} / \mathrm{s}$, namun ketika daya gelombang mikro yang digunakan sebesar 600 dan 800 watt menghasilkan nilai viskositas kinematik yang sama yaitu sebesar $5,16 \mathrm{~mm}^{2} / \mathrm{s}$. Data dari Gambar 4 juga menunjukkan bahwa produk biodiesel yang dihasilkan pada daya 450 hingga 800 watt nilai viskositas kinematiknya masih masuk dalam rentang persyaratan SNI 7182-2012 yaitu pada rentang 2,3 $6,0 \mathrm{~mm}^{2} / \mathrm{s}$. Ketidak sesuaian nilai viskositas biodiesel berpengaruh terhadap suplai biodiesel ke ruang bakar mesin diesel dimana jika nilai viskositas kinematik terlalu rendah menyebabkan kebocoran pada sistim pompa injeksi dan proses atomisasi bahan bakar kurang sempurna sebaliknya jika nilai viskositas kinematik terlalu tinggi dari yang dipersyaratkan dapat menghambat proses injeksi biodiesel dan secara keseluruhan akan berpengaruh terhadap kinerja mesin diesel (Yoon et al., 2008).

\section{Angka Asam}

Angka asam sangat berpengaruh terhadap kualitas biodiesel dimana jika angka asamnya tingi semakin rendah kualitas biodiesel. Angka asam yang tinggi di dalam biodiesel menunjukkan adanya kandungan asam lemak bebas (free fatty acid) yang nantinya dapat menyebabkan korosi pada pompa injeksi bahan bakar dan dapat membentuk sendimen (deposit) dalam ruang bakar yang dapat mempengaruhi kinerja mesin diesel (Saifuddin et al., 2009).

Perbedaan angka asam dari produk biodiesel yang dihasilkan berdasarkan besaran daya gelombang mikro yang dipancarkan disajikan pada Gambar 5. 


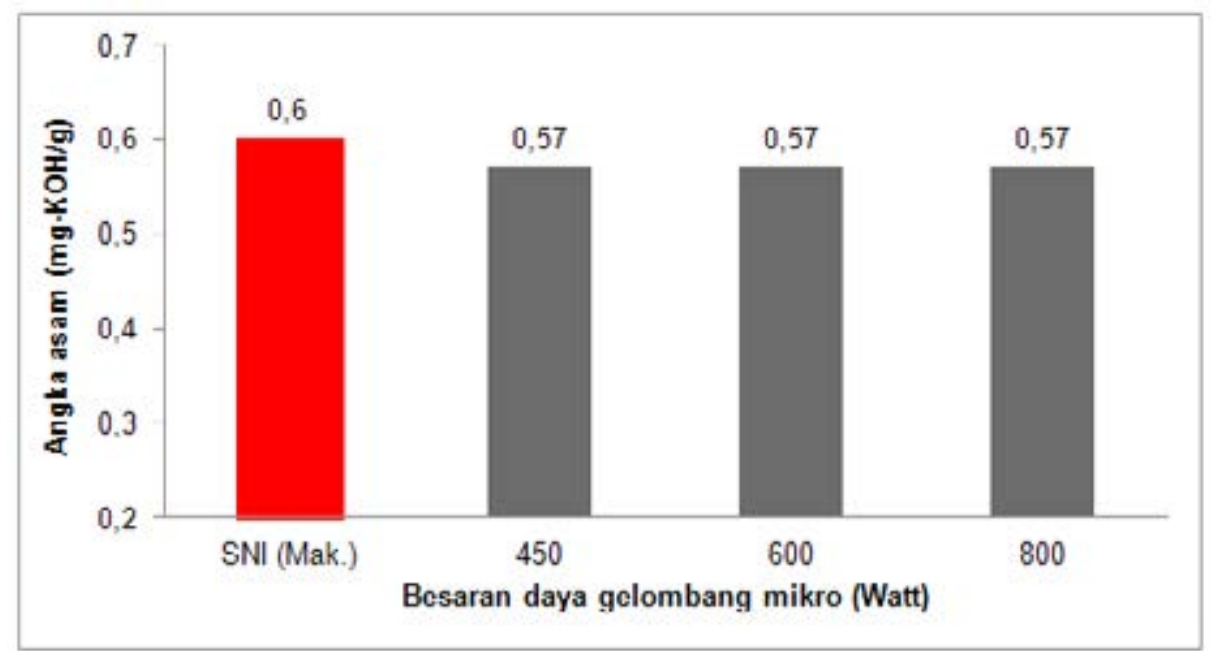

Gambar 5. Pengaruh Besaran Daya Gelombang Mikro Terhadap Angka Asam Biodiesel

Data dari Gambar 5 menunjukkan bahwa besaran daya gelombang mikro yang dipancarkan tidak berpengaruh terhadap nilai angka asam dari produk biodiesel yang dihasilkan. Besaran daya gelombang mikro yang dipancarkan pada variasi 450, 600 dan 800 Watt menghasilkan angka asam yang sama yaitu sebesar $0,57 \mathrm{mg}-\mathrm{KOH} / \mathrm{g}$. Angka asam dari ketiga jenis perlakuan tersebut masih memenuhi standar SNI 7182-2012 yaitu angka asam maksimum $0,6 \mathrm{mg}-\mathrm{KOH} / \mathrm{gr}$.

\section{Komponen Biodiesel}

Produk biodiesel yang diperoleh dari hasil transesterifikasi in situ pada pancaran daya gelombang mikro 450, 600 dan 800 watt, sampelnya diambil dan dianalisa komponennya menggunakan peralatan Gas Chomatography-Massa (GCMS). Analisa ini menghasilkan puncak-pucak kromatogram yang menunjukkan jenis-jenis komponen biodiesel spesifik. Hasil pengujian komponen biodiesel menggunakan GCMS ditampilkan pada Tabel 1.

Tabel 1. Kromatogram Biodiesel Berdasarkan Daya Gelombang Mikro

\begin{tabular}{crccc}
\hline \multirow{2}{*}{ No. } & \multirow{2}{*}{ Nama Komponen } & \multicolumn{3}{c}{ Jumlah Komponen (\%) } \\
\cline { 3 - 5 } & & $\mathbf{4 5 0}$ Watt & $\mathbf{6 0 0}$ Watt & $\mathbf{8 0 0 ~ W a t t}$ \\
\hline 1 & Metil Stearat & 52,21 & 52,90 & 56,56 \\
2 & Metil Palmitat & 44,31 & 42,03 & 40,23 \\
3 & Metil Miristat & 1,18 & 3,40 & 1,75 \\
4 & Lain-Lain & 1,97 & 1,60 & 1,15 \\
& & $\mathbf{9 9 , 6 7}$ & $\mathbf{9 9 , 9 3}$ & $\mathbf{9 9 , 6 9}$ \\
\hline
\end{tabular}

Data pada Tabel 1 menunjukkan bahwa kadar metil ester yang terdapat dalam produk biodiesel pada perlakuan dengan pancaran daya gelombang mikro 450, 600 dan 800 watt menghasilkan variasi komponen yang tidak mengalami perubahan signifikan dengan komponen utama berupa metil stearat, metil palmitat, metil miristat dan komponen lainnya dalam jumlah kecil. Hasil pengujian GC-MS ini hampir sama dengan hasil peneltian yang dilakukan oleh Aziz et al (2016) pada proses sintesa biodiesel menggunakan biji kemiri yang menghasilkan komponen utama berupa 
metil stearate, metil palmitat dan komponen lainnya namun dengan persentase yang berbeda. Dari data pada Tabel 1 juga dapat dilihat bahwa jumlah total komponen biodiesel pada daya gelombang mikro 450 , 600 dan 800 watt nilai rata-ratanya diatas 99\% dimana nilai tersebut masih memenuhi standar SNI 7182-2012 yaitu kadar ester metil min. 96,5\%-massa.

\section{SIMPULAN}

Proses sintesa biodiesel dari biji kemiri secara transesterifikasi in situ dengan bantuan gelombang mikro pada daya 450 , 600 dan 800 watt menghasil rendemen tertinggi sebesar $85,58 \%$ pada pancaran daya gelombang mikro 600 watt. Hasil pengujian mutu biodiesel sesuai dengan SNI 7182-2012 pada daya gelombang mikro 400, 600 dan 800 watt menunjukkan nilai viskositas kinematik dan angka asam masih memenuhi standar SNI, sedangkan hasil pengujian massa jenis belum memenuhi persyaratan SNI. Sementara itu, hasil uji komponen biodiesel menggunakan GC-MS diketahui kandungan utama biodiesel dari biji kemiri berupa metil stearat 52,21\% (450 watt), 52,90\% (600 watt), 56,56\% (800 watt); metil palmitat $44,31 \%$ (450 watt), $42,03 \%$ (600 watt), 40,23\% (800 watt); metil miristat $1,18 \%$ (450 watt), 3,40\% (600 watt) dan $1,75 \%$ (800 watt). Dapat disimpulkan bahwa besaran daya gelombang mikro berpengaruh terhadap perolehan rendemen biodiesel, tetapi mutu dan komponen biodiesel tidak berpengaruh signifikan terhadap perbedaan daya gelombang mikro.

\section{DAFTAR PUSTAKA}

1. Alptekin E., Canakci M, 2008. Determination of density and the viscosities of biodiesel-diesel fuel blends. Renewable Energy. 33 (12) : 26232630.

2. Aziz R., Aisyah., Ilyas A, 2016. Sintesis metil ester dari minyak biji kemiri (Aleurites moluccana) menggunakan metode ultrasonokimia. Al-Kimia, 4 (1) : 21-29.
3. Dwivedi G., Jain S., Sharma M.P, 2013. Diesel engine performance and emission analysis using biodiesel from various oil sources-Review. Journal of Materials and Environmental Science, $4: 434-447$.

4. Haas J.M., Scott M.K., Foglia A.T., Marmer N.W, 2007. The general applicability of in situ transesterification for the production of fatty acid esters from a variety of feedstocks. Journal of the American Oil Chemists' Sociaty, 84 : $963-970$.

5. Haryanto A., Silviana U., Triyono S., Prabawa S, 2015. Produksi biodiesel dari transesterifikasi minyak jelantah dengan bantuan gelombang mikro: Pengaruh intensitas daya dan waktu reaksi terhadap rendemen dan karakteristik biodiesel. Agritech, 35 (2), pp. 234-240.

6. Jain S., Sharma M.P, 2010. Prospect of biodiesel from jathropha in India. Renewable and Sustainable Energy Reviews, 14 : 763-771.

7. Marwan., Suhendrayatna., Indarti E, 2015. Preparation of biodiesel from microalgae and palm oil by direct transesterification in batch microwave reactor. Journal of Physic : Confrence Series, 622 : 1- 8.

8. Mittelbach M., Remschmidt C. (2004). Biodiesel: The Comprehensive Handbook. Mittelbach. Graz, Austria.

9. Oxfam, 2014. Food, fossil fuels and filthy finance. Oxfam Breifing Paper. Oxfam Briefing Paper. https://oxfamilibrary. openrepository.com/.../bp191 fossil-fuels-finance-climate-change171014-en.pdf. [5 Maret 2018].

10. Ramos M.J., Fernandes M.C., Casas A, Rodriguez L., Perez A, 2009. Influence of fatty acid composition of raw materials on biodiesel properties. Bioresources Technology, 100 (1) : 261-268.

11. Refaat AA., El Sheltawy T.S., Sadek U.K, 2008. Optimum reaction time, performance and exhaust emissions 
of biodiesel produced by microwave irradiation. International Journal of Environmental Science \& Technology. 5 (3) : 315-322.

12. Saifuddin N., Raziah Z.A., Farah N.H, 2009. Production of biodiesel from high acid value waste cooking oil using an optimized lipase enzyme/acidcatalyzed hybrid process. E-Journal of Chemistry, 6 (S1) : S485-S495.

13. Saifuddin N., Chua H.K, 2004. Production of ethyl ester (biodiesel) from used frying oil: Optimization of transesterification process using microwave irradiation. Malaysian Journal of Chemistry, 6 (1):77-82.

14. SNI (2006). SNI 7182-2012: Biodiesel. Badan Standarisasi Nasional (BSN).

15. Saraf S., Thomas B, 2007. Influence of feedstock and process chemistry on biodiesel quality. Process Safety and Environmental Protection, 85 : 360 364.

16. Sundaryono A, 2011. Karakteristik biodiesel dan blending biodiesel dari oil losses limbah cair pabrik minyak kelapa sawit. Jurnal Teknologi Industri Pertanian. 21:34-40.
17. Surati A.M., Jauhari S., Desai R.K, 2012. A brief review: microwave assisted organic reaction. Archieves of Applied Science Research, 4 (1) : 646-661.

18. Xue J., Grift T.E., Hansen A.C, 2011. Effect of biodiesel on engine performance and emissions. Renewable and Sustainable Energy Reviews, 15 (2) : 1098-1116.

19. Yoon HS., Park HS., Lee SC, 2008. Experimental investigation on the fuel properties of biodiesel and its blends at various temperatures. Energy \& Fuel, 22 (1) : 652-656.

20. Zare M., Ghobadian B., Fayyazi E., Najafi G., Hosseinzadeh B, 2013. Microwave-assisted biodiesel fuel production from waste cooking oil. Agriculture and Crop Sciences, 15 (12) : 1314-1317. 